Geopolítica(s) Revista de estudios sobre espacio y poder ISSN: 2172-3958

https://dx.doi.org/10.5209/geop.68656

\title{
Poder político e desenvolvimento urbano em Salvador: tendências das últimas décadas
}

\author{
Rafael de Aguiar Arantes ${ }^{1}$ y Carla Galvão Pereira ${ }^{2}$
}

Recibido: 2 de abril de 2020 / Aceptado: 23 de agosto de 2020

Resumo. Este trabalho analisa a configuração do poder político em Salvador e suas vinculações com o desenvolvimento urbano da cidade. Busca-se compreender as relações intergovernamentais da prefeitura municipal com o governo do estado e suas relações com a coalizão de interesses privados dos chamados "capitais do urbano". O artigo parte do processo de metropolização da cidade nos anos 70 e chega às transformações contemporâneas que, desde a década de 90, vem caracterizando Salvador como uma cidade voltada para um empresariamento urbano que aposta no turismo, na produção imobiliária e na realização de atividades lúdico-culturais. O trabalho se baseou em pesquisa bibliográfica e na coleta de informações em documentos, relatórios de gestão, jornais e revistas, peças publicitárias dos governos e discursos dos gestores. Os resultados ilustram os dilemas de uma cidade pobre e periférica cujo processo de desenvolvimento urbano esteve vinculado aos interesses de diversos capitais do urbano e de uma elite política regional. Atualmente a gestão urbana do município tem sido objeto de uma competição intergovernamental entre os poderes públicos municipal e estadual que, embora de coalizões político-partidárias distintas, operam dentro de lógicas semelhantes de intervenção, baseadas num amplo programa de empresariamento da gestão urbana.

Palavras-chave: governo empresarial; empreendedorismo urbano; coalizões políticas; máquinas de crescimento; Salvador.

\section{[es] Poder político y desarrollo urbano en Salvador: tendencias de las últimas décadas}

Resumen. Este artículo analiza la configuración del poder político en Salvador y sus vínculos con el desarrollo urbano de la ciudad. Busca comprender las relaciones intergubernamentales entre el gobierno municipal y el gobierno del estado y sus relaciones con la coalición de intereses privados de los llamados "capitales de lo urbano". El artículo parte del proceso de metropolización de la ciudad en la década de 1970 y llega a las transformaciones contemporáneas que, desde la década de 1990, han caracterizado a Salvador como una ciudad enfocada en el emprendimiento urbano que se enfoca en el turismo, la producción inmobiliaria y en la realización de actividades recreativas y culturales. El trabajo se basó en investigación bibliográfica y en la recopilación de información en documentos,

1 Departamento de Sociologia da Universidade Federal da Bahia (Brasil). Pesquisador do núcleo Salvador do INCT/Observatório das Metrópoles.

E-mail: rafaelarantes13@gmail.com

2 Departamento de Ciência Política da Universidade Federal da Bahia (Brasil). Pesquisadora do núcleo Salvador do INCT/Observatório das Metrópoles.

E-mail: galvaocp@yahoo.com.br 
informes de gestión, periódicos y revistas, anuncios gubernamentales y discursos de los administradores. Los resultados ilustran los dilemas de una ciudad pobre y periférica cuyo proceso de desarrollo urbano estaba vinculado a los intereses de varios capitales de lo urbano y a una élite política regional. Actualmente, la gestión urbana del municipio ha sido objeto de competencia intergubernamental entre las autoridades públicas municipales y estatales, las cuales, aunque desde distintas coaliciones de partidos políticos, operan dentro de una lógica de intervención similar, basada en un amplio programa de emprendimiento de gestión urbana.

Palabras clave: gobierno empresarial; emprendimiento urbano; coaliciones políticas; máquinas de crecimiento; Salvador.

\title{
[en] Political Power and Urban Development in Salvador: Trends of the Last Decades
}

\begin{abstract}
This paper analyzes the configuration of political power in Salvador and its links with the urban development of the city. It seeks to understand the intergovernmental relations between the municipal government and the state government and its relations with the coalition of private interests of the so-called "capitals of the urban". The article starts from the city's metropolization process in the 1970s and reaches contemporary transformations that, since the 1990s, have characterized Salvador as a city focused on urban entrepreneurship that focuses on tourism, real estate production and carrying out recreational and cultural activities. The work was based on bibliographic research and on the collection of information in documents, management reports, newspapers and magazines, government advertisements and speeches by managers. The results illustrate the dilemmas of a poor and peripheral city whose urban development process was linked to the interests of several urban capitals and a regional political elite. Currently, the urban management of the municipality has been the subject of intergovernmental competition between the municipal and state public authorities, which, although from different political-party coalitions, operate within similar logic of intervention, based on a broad entrepreneurial program of urban management.
\end{abstract}

Keywords: corporate governance; urban entrepreneurship; political coalitions; growth machines; Salvador.

Sumario. Introdução. 1. Carlismo, modernização conservadora e vulnerabilidade do poder local em Salvador. 2. Empresariamento urbano e laissez-faire territorial em Salvador na virada do século XX. 3. A gestão urbana na Salvador contemporânea: governo empresarial e competição intergovernamental. À guisa de considerações finais. Agradecimentos. Referencias.

Cómo citar: Arantes, R. de A., y Pereira, C. G. (2020). Poder político e desenvolvimento urbano em Salvador: tendências das últimas décadas. Geopolítica(s). Revista de estudios sobre espacio y poder, $11(2), 287-312$.

\section{Introdução}

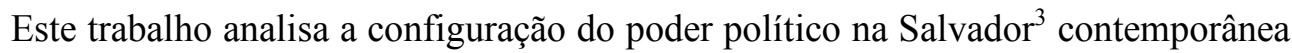
e suas vinculações com o desenvolvimento urbano da cidade. Busca-se compreender as relações intergovernamentais da prefeitura municipal com o governo do estado e suas relações com a coalizão de interesses privados, especialmente dos chamados "capitais do urbano" (Marques, 2016).

3 Primeira capital do Brasil e atualmente a quarta maior cidade do país com uma população estimada de 2.872.347 pessoas em 2019 . 
O artigo parte do processo de modernização industrial e urbana da cidade nos anos 60 e 70, caracterizando o poder local e as alianças econômicas formadas desde então. Avança pela trajetória dessas relações ao longo do processo de democratização nos anos 80 e chega às transformações mais contemporâneas que, desde a década de 90, vem caracterizando Salvador como uma cidade voltada para um empresariamento urbano que aposta no turismo, na produção imobiliária e na realização de atividades lúdico-culturais para a atração de fluxos de pessoas e capitais (Harvey, 1996).

$\mathrm{O}$ trabalho se fundamentou em pesquisa bibliográfica para compreender as características da gestão urbana em Salvador desde a sua modernização. Baseou-se também na coleta de dados secundários, especialmente documentos oficiais (peças publicitárias dos governos, planos de gestão, discursos dos gestores públicos, diário oficial e contratos de parcerias público-privadas) e material jornalístico ${ }^{4}$, que foi obtido a partir de uma pesquisa no acervo do jornal $A$ Tarde, o mais importante do estado, e em portais de notícias de outros veículos de comunicação. Foram selecionadas reportagens que continham referências ao desenvolvimento urbano da cidade (planos de gestão, legislação urbanística, empreendimentos públicos e privados, etc.) e que apresentavam discursos dos gestores públicos, já que se acredita, como fundamento teórico-metodológico, que suas posições, valores e alinhamentos ideológicos podem ser identificados em pronunciamentos públicos. É importante salientar que as informações obtidas através das fontes jornalísticas, especialmente os valores dos projetos analisados, foram cotejadas com dados oficiais.

Esta pesquisa se concentrou entre 2013 e 2020, período que converge com o início da gestão do atual prefeito ACM Neto, filiado ao Partido Democratas (DEM). Nesse momento começa a se processar uma competição intergovernamental entre a prefeitura municipal de Salvador (PMS) e o governo do estado, liderado pelo Partido dos Trabalhadores (PT) desde 2007.

As transformações ocorridas nas últimas décadas, com a reestruturação produtiva, a globalização e o neoliberalismo, tiveram grande repercussão no funcionamento das grandes cidades, em sua estrutura econômica, urbana, social e política. Dentro desse processo de transição geral da dinâmica do regime de acumulação de capital fordista-keynesiano para um regime de "acumulação flexível" (Harvey, 1996, p.50), destaca-se, entre outros aspectos, uma reorientação da ação dos governos urbanos, que cada vez mais se voltam ao empresariamento, propondo uma conexão mais estreita entre os setores privado e público.

Nesse período, tem início uma transformação geral da natureza da regulação do Estado. Como apontam os estudos das teorias da regulação, a lógica de um Estado intervencionista cede espaço para uma política reguladora e de promoção da competição como as modalidades principais da intervenção pública na economia. As novas políticas regulatórias têm por objetivo instaurar um mercado plenamente competitivo (Rivera, 2004).

Para Dardot e Laval (2016), a nova razão neoliberal que fundamenta esse processo construiu a figura do "governo empresarial", um novo padrão governamental que não se pauta num simples abandono das funções tradicionais de planejamento e

4 Para Duverger (1981), a imprensa constitui uma fonte de documentação essencial, pois grande número de fatos políticos só é acessível através dela, especialmente quando os arquivos não estão disponíveis ou a falta de transparência dos dados oficiais impede o conhecimento público mais amplo. 
gestão do Estado e sua terceirização aos mercados, mas numa reconfiguração da própria lógica da ação estatal, que passa a ser regida pelas regras da concorrência e submetida às exigências de eficácia, como nas empresas privadas. $\mathrm{O}$ neoliberalismo transformou a ação pública construindo uma afinidade profunda entre os sentidos das esferas pública e privada, criando uma "mercadorização da instituição pública". A lógica do bem-estar é substituída pela ideia de concorrência, desempenho e pela lógica do custo/benefício, incorporando o gerencialismo como fundamento das decisões públicas (Dardot e Laval, 2016).

Tal qual uma "nova razão do mundo" (Dardot e Laval, 2016), os governos urbanos também têm assumido uma reorientação para a lógica da competição baseada no mercado. Entretanto, como destacou Brenner (2018), a neoliberalização é um processo variegado; embora sistêmico, se expressou através de diversificação regulatória e diferenciação geoinstitucional em lugares, territórios e escalas. Seu caráter sistêmico é dado pelo fato de que experimentos regulatórios realizados localmente nos anos 70 se transformaram nos anos $80 \mathrm{em}$ um sistema interjurisdicional de políticas compartilhado em redes de conhecimento e, nos anos 90, em regimes de normas transnacionais baseados em arranjos institucionais de larga escala, arcabouços regulatórios, sistemas legais e revezamentos de políticas que impõem as "regras do jogo" através de instituições como a OMC, o FMI, o Banco Mundial e a OCDE, por exemplo. Sua variegação, por sua vez, depende do fato de que este processo apresenta uma forte dependência de trajetória das paisagens institucionais anteriores, como o fordismo, nacional-desenvolvimentismo ou o socialismo de estado (Brenner, 2018). Em síntese, a neoliberalização que dá origem aos governos urbanos empresariais "[...] representa uma tendência historicamente específica, desenvolvida de maneira desigual, híbrida e padronizada de reestruturação regulatória disciplinada pelo mercado" (Brenner, 2018, p.165).

As estratégias de empresariamento urbano partem do princípio de que os governos locais precisam ser mais inovadores e empreendedores. Isso se expressa na atração de novos investimentos diretos e fontes geradoras de emprego, especialmente através do incentivo de parcerias público-privadas, e na produção de renovações urbanas a partir de empreendimentos imobiliários, como um novo centro cívico ou uma nova zona industrial.

De maneira geral, Harvey (1996) destaca quatro grandes estratégias para alcançar esses objetivos:

a) a exploração de vantagens específicas locais na competição internacional para a produção de bens e serviços (infraestruturas físicas e sociais, novas tecnologias, mão de obra qualificada e subsídios);

b) a participação na competição internacional através da divisão espacial do consumo (turismo, inovações culturais, elevação na qualidade do meio urbano, atrativos de consumo como shoppings, marinas, centros de convenções, etc.), pois como destacou o autor "acima de tudo, a cidade tem que parecer como um lugar inovador, excitante, criativo e seguro para viver, visitar, para jogar ou consumir" (Harvey, 1996, p.55);

c) a disputa global para assumir o controle e as funções de comando de altas operações financeiras, de governo ou de centralização e processamento, acessível apenas aos grandes nós da rede global, e 
d) a competição pela redistribuição dos excedentes do governo central, dimensão característica, em especial, do desenho federativo estadunidense.

As estratégias de empresariamento urbano são levadas a cabo por coalizões políticas complexas e heterogêneas, mas que, segundo Logan e Molotch (1987), se organizam para colocar em marcha "máquinas de crescimento", que buscam construir ciclos de crescimento baseados em renovação urbana e produção imobiliária. Tais máquinas são impulsionadas por capitalistas locais envolvidos com investimentos em propriedades, incorporação e financiamento imobiliários, que buscam participar das políticas urbanas. Mas diversos outros atores interferem no seu funcionamento, entre eles as elites políticas, que podem servir para maximizar as políticas pró-crescimento. Swanstrom (1985 apud Logan e Molotch, 1987) identificou dois tipos de estrategistas de crescimento, os que aderem ao modelo do livre mercado, operando uma espécie de "capitalismo irrestrito", e aqueles que reconhecem que os planos e ações de governo podem servir para propiciar um crescimento de longo prazo, cooptando e pacificando a oposição, colocando em prática um "capitalismo pragmático de estado".

Desde os anos 90, as práticas de empresariamento dos governos urbanos, e seus discursos de crescimento, vem sendo levados a cabo através do chamado planejamento estratégico, que entende que as cidades devem ser mais competitivas frente aos desafios da globalização e, para tal, devem se ser geridas não apenas "like business" mas antes "for business" (Arantes, 2000). Das cidades americanas, o modelo se difundiu para as cidades europeias, entre elas Barcelona, que se tornou referência mundial e cuja experiência passou a ser exportada, especialmente para a América Latina, através da forte agência de organismos multilaterais e da influência de consultores internacionais, sobretudo catalães (Vainer, 2000).

Manuel Castells e Jordi Borja (1996, p.152), por exemplo, entendem as cidades "como atores sociais complexos de múltiplas dimensões" que deveriam articular as administrações públicas, os agentes econômicos, as organizações sociais e cívicas, entre outras. Para eles, as grandes cidades deveriam responder a objetivos tais como a construção de uma nova base econômica, ampliação da infraestrutura urbana e da qualidade de vida, produção de integração social e aperfeiçoamento da governabilidade. Somente gerando capacidades de resposta a estes propósitos poderiam, por um lado, ser competitivas para o exterior, se inserindo nos espaços econômicos globais e, por outro, dar garantias a sua população de um mínimo de bem-estar para que a convivência democrática pudesse se consolidar.

Cada cidade deveria ter um projeto de transformação urbana, assentado num planejamento estratégico que buscasse construir uma "negociação entre os atores urbanos, públicos e privados, e a geração de uma liderança local (política e cívica)" (Castells e Borja, 1996, p.156). Os governos locais, portanto, deveriam assumir um papel de promotor e empreendedor, buscando obter novas competências, novos recursos e novas formas de gestão.

De fato, segundo Herrschel e Newman (2017), no mundo globalizado as cidades têm se tornado cada vez mais presentes como atores subnacionais conscientes dos seus direitos e do seu papel regional, assim como estão mais engajadas na formulação de políticas e na governança internacionais. Isso vem ocorrendo através do engajamento em redes coletivas e da participação em organizações internacionais de modo cada vez mais autônomo frente aos governos centrais. Assim, essas enti- 
dades subnacionais, cidades, cidades-regiões e regiões passam a navegar por teias globais cada vez mais complexas de redes de relações formais e informais, verticais e horizontais, na busca de oportunidades e promoção dos interesses locais e regionais.

Assim, há um esforço crescente para a atração de capitais internacionalmente móveis a partir de estratégias mais "proativas", engendrando conexões e alianças, mas também competição e rivalidades. Perder essas conexões, ou ser ignorado por elas, produz e reforça formas de marginalidade e exclusão. As cidades e regiões com menor capacidade de ação ou menor integração nas redes internacionais ficam alijadas desses processos ou têm menores condições de se integrar de maneira mais autônoma e proativa (Herrschel e Newman, 2017).

Segundo Vainer (2000), o modelo de planejamento estratégico pautado no empresariamento urbano articula três analogias sobre as cidades contemporâneas: a cidade mercadoria, a cidade empresa e a cidade pátria. Em primeiro lugar, a cidade precisa ser uma mercadoria atrativa para ser vendida no mercado externo extremamente competitivo e, para tanto, é necessária a utilização cada vez maior do marketing urbano. Ela também é vista como uma empresa, ou seja, é também um sujeito que busca ter produtividade e competitividade, aproximando-se dos setores privados "estrategicamente relevantes", de modo que "a analogia da cidade-empresa desliza, suave e sutilmente, para uma analogia cidade-empresários" (Vainer, 2000, p.89).

Por fim, para garantir a realização plena do espaço urbano enquanto mercadoria e sujeito empresarial busca-se construir condições simbólicas de legitimação dessas estratégias através do orgulho e do sentimento cívico pela cidade, conformando uma "cidade pátria". Essa lógica abre espaço para a construção de "um governo forte, personalizado, estável, apolítico e carismático" (Vainer, 2000, p. 97) com capacidade para manter a trégua e a coesão interna. Segundo Arantes (2000), esse modelo de gestão urbana se tornou um "pensamento único" sobre a cidade, sendo aplicado por governos dos mais diversos matizes políticos.

Considerando todas essas tendências de transformação da gestão urbana nos últimos anos e a ressalva sobre o caráter variegado desses processos (Brenner, 2018), é importante destacar a complexidade de um trabalho que pretende analisar poder político e desenvolvimento urbano. Um estudo amplo sobre o tema precisa, de alguma forma, considerar tanto a ação dos agentes públicos, do executivo e do legislativo, quanto as formas de cooperação e conflito e a participação dos agentes econômicos e da sociedade civil.

Essa complexidade é destacada pela chamada teoria dos regimes urbanos nas suas análises sobre as coalizões de base local. Segundo Stone (1993), um regime local ou nacional é conformado por arranjos políticos que constroem uma divisão do trabalho entre as instituições governamentais e alguns grupos privados. Em busca de uma economia política do espaço, esta teoria pressupõe que as instituições de governo são moldadas tanto pela economia, no que tange aos investimentos privados, quanto por políticos eleitos em contextos competitivos. Dessa forma, as políticas públicas seriam moldadas pela composição da coalizão de governo, pela natureza da relação entre os membros da coalizão e pelos recursos que os membros trazem para ela.

Para Stone (1993), a efetividade de um governo local depende altamente da cooperação dos atores não-governamentais, já que as coalizões tendem a ter estabili- 
dade e ser protegidas pelos participantes. Nesse sentido, a teoria dos regimes foca na natureza e na composição dessa coalizão, perguntando como e por que algumas preocupações ganham atenção e outras não.

$\mathrm{O}$ autor construiu uma tipologia dos regimes urbanos dentro do contexto das cidades estadunidenses:

a) regime de manutenção, quando se mantém os serviços de rotina, baixa mobilização de recursos privados e baixos impostos;

b) regime de desenvolvimento, parecido ao que Molotch (1976) chamou de "máquinas de crescimento", é baseado em mudanças no uso da terra, envolve vínculos com investimentos privados; se baseia na coordenação de elites e por isso é socialmente insulado e, muitas vezes, controverso;

c) regime progressista de classe média, focado em medidas de proteção ambiental, histórica, de qualidade de vida urbana, etc.; requer regulação das elites e atividades econômicas e participação social, já que tende a ser mais difícil de ser governado, e

d) regime voltado à expansão das oportunidades das classes baixas (regime hipotético, que envolve melhorias na educação, no transporte, na ampliação de oportunidades de emprego e negócios e requer não apenas regulação estatal mas modificação das práticas do setor privado através de uma coordenação das elites).

Analisando as chamadas "políticas do urbano" dentro do contexto social, econômico e político-institucional do Brasil, Marques (2017) caracteriza o processo de produção dessas políticas a partir do que chamou de "tecido relacional do Estado e de sua permeabilidade", que expressa "os padrões de conexões entre atores estatais e não estatais em redes baseadas em relações formais e informais de diversos tipos". O Estado é entendido como central na produção dessas políticas, mas sendo permeável ao setor privado. Para o autor, o estudo das políticas do urbano requer a compreensão de três elementos da política em geral:

a) instituições, agências e processos de produção de políticas (regras formais, desenhos organizacionais e seus múltiplos elementos, governo, burocracia, etc.);

b) atores societais, suas relações entre si e com o Estado (os políticos, os capitais do urbano e os coletivos da sociedade civil), e

c) legados e processos que as produzem ${ }^{5}$.

Alguns elementos dessa discussão são importantes. Em primeiro lugar, uma análise das instituições requer uma compreensão dos diversos níveis de governo, do desenho federativo, das cadeias de produção das políticas, das burocracias de

Em pesquisas em Buenos Aires, Jajamovich (2013) identificou a relevância também da circulação internacional de ideias na conformação das políticas urbanas. Elas seriam muitas vezes construídas através da influência (não replicação acrítica, já que envolvem disputas e readaptações) de uma ampla rede de atores locais, nacionais e internacionais, que divergem sobre os modos de formulação e implementação dessas políticas. 
nível de rua e da dependência de trajetória ${ }^{6}$, que tende a ser mais relevante nas políticas urbanas devido a sua vinculação com o espaço físico (Marques, 2017).

Em segundo lugar, o autor chama a atenção para a relevância dos atores societais e suas relações, a começar pelos políticos, como destacaram Logan e Molotch (1987) e Stone (1993). A ação da elite política é extremamente importante na conformação das políticas do urbano, uma vez que delas muitas vezes depende a maximização das chances de reeleição dos prefeitos e dos políticos de base local. Segundo Marques (2017), a imbricação entre Legislativo e Executivo é maior no âmbito municipal, de modo que o controle sobre áreas do executivo se torna muitas vezes central para a construção de carreiras políticas baseadas em recursos clientelistas.

Um terceiro ponto é a relevância dos chamados "capitais do urbano", ou seja, "as empresas privadas cujos ciclos de valorização se ligam à produção da cidade e às políticas do urbano em sociedades capitalistas - concessionárias de transportes e limpeza, incorporadoras, construtoras etc." (Marques, 2016, p.10). Ele sugere quatro conjuntos de capitais: a) o capital incorporador; b) os serviços públicos c) o capital da construção civil e d) a prestação de serviços de consultoria, apoio à gestão e gerenciamento do próprio Estado nas políticas urbanas. Destacam-se ainda os atores coletivos da sociedade civil, agentes não estatais que se inserirem na formulação de políticas públicas e que estão conectados entre si e com agentes do Estado no interior do seu "tecido relacional", conformando uma rede dos setores de políticas em constante transformação.

Para o presente trabalho interessam especialmente as relações entre os atores políticos e os capitais do urbano, bem como a dependência de trajetória que conforma um legado histórico marcado no Brasil por uma "grande interpenetração das elites políticas e econômicas locais com esses capitais, gerando múltiplos canais para a influência do setor privado sobre as políticas do urbano" (Marques, 2017, p.13). Nesse aspecto, o trabalho busca analisar a lógica da ação política sobre o espaço urbano, considerando a influência do contencioso político-eleitoral e dos múltiplos interesses dos capitais do urbano. Assim, busca analisar as coalizões de interesse público-privado e as estratégias de gestão urbana colocadas em prática em Salvador.

\section{Carlismo, modernização conservadora e vulnerabilidade do poder local em Salvador}

Salvador, capital do estado da Bahia, cidade colonial rica em cultura e patrimônio histórico, teve uma expansão econômica e populacional extraordinária a partir dos anos 50, culminando com um processo de metropolização que se aprofundou nos anos 70 associado ao desenvolvimento do seu capitalismo industrial.

As transformações urbanas ocorridas em Salvador nesse período estiveram fortemente vinculadas à conformação de uma elite política longeva na Bahia, denomi-

6 Este conceito é discutido pelos autores do chamado institucionalismo histórico, que enfatizam a relevância da história e de uma causalidade social dependente da trajetória percorrida. Nesse caso, as instituições aparecem como integrantes relativamente permanentes da paisagem da história assim como um dos principais fatores que mantém o desenvolvimento histórico sobre um conjunto de trajetos (Hall e Taylor, 2003). 
nada de "carlismo", termo utilizado para designar o grupo formado em torno da forte liderança de Antônio Carlos Magalhães (ACM), que foi a condutora da modernização conservadora na Bahia (Dantas Neto, 2006).

Em 1967, ACM foi nomeado prefeito de Salvador pelo regime autoritário. Uma vez no cargo conduziu, com grande velocidade e por vezes com recurso à truculência, a modernização capitalista da cidade desbloqueando a antiga estrutura fundiária pré-capitalista e dando vida aos principais vetores de expansão urbana da Salvador moderna (Brandão, 1978). A Lei da Reforma Urbana de 1968 propiciou a alienação nesse período de 4.680 hectares de terras públicas, fato que "permitiu a expansão (e especulação) imobiliária da cidade nas décadas seguintes" (Vasconcelos, 2002, p.361).

Por conta desse feito, ACM recebeu da Câmara Municipal de Salvador o diploma de "Prefeito do Século". Sua administração contribuiu também para a sua indicação, pelo então Presidente Militar, mediante apoio majoritário da representação regional do partido governista (Arena), à eleição indireta para o Governo do Estado da Bahia em 1971. Na condição de governador, liderou um conjunto de transformações que ilustram o direcionamento da órbita de acumulação urbana para o capital da construção civil e incorporador, especialmente a partir de dois empreendimentos, as construções da Avenida Luiz Viana Filho, conhecida como Paralela, e do Centro Administrativo da Bahia, que tiveram um papel importante na constituição de um vetor de crescimento da cidade.

Chegando ao governo, ACM indicou Clériston Andrade para a PMS, gestão que foi profundamente dependente do governo estadual, que ampliava sua intervenção sobre o espaço urbano da cidade, e do líder dessa elite política que começara se fortalecer. Conforme definiu Dantas Neto (2000, p.55), tal gestão "[...] foi emblemática dessa nova configuração do poder local, equiparado ao status político de uma secretaria estadual, mas cumprindo novo e importante papel de indutor da acumulação imobiliária".

A partir daí, segundo o referido autor, o poder político local de Salvador se tornou profundamente vulnerável ao condicionamento do forte poder estadual e ao contencioso político que se forma para disputá-lo. O governo do estado abriga a força hegemônica dominante da política baiana, que, mesmo quando não dá diretamente as cartas, consegue ditar a agenda política do poder local, conformando aquilo que Dantas Neto (2000, p.82) chamou de "modo baiano de governar Salvador".

Deriva diretamente desta tese, ainda que o referido autor não o conclua, que o poder local em Salvador tem sido historicamente vulnerável também, ou melhor, atrelado aos interesses de grupos privados, especialmente do mercado imobiliário e das empreiteiras. A modernização da cidade, assim, foi produzida pela lógica da "sagrada aliança" conformada entre os setores do capital internacional e do capital nacional, mediatizada pela ação do Estado; à fração nacional coube as atividades de especulação imobiliária e de construção urbana, que foram realizadas a partir de uma acumulação artificial que permitiu a obtenção de uma massa pervertida de lucros (Lessa e Dain, 1981).

Tal vinculação se deu, inclusive, para além do grupo carlista. Na gestão do prefeito Jorge Hage (1975-1977), por exemplo, houve uma tentativa de modernizar a prefeitura pela via tecnocrática, fazendo-a assumir o papel de planejar e controlar o desenvolvimento urbano e a acumulação imobiliária. O projeto se viu fracassado 
pela influência das elites econômicas frente ao governo do estado e pela vigência da ordem autoritária no país. Outros gestores municipais, como Mário Kertész (1979-1981; 1986-1988), Manoel Castro (1983-1985), Fernando José (1989-1992) e Lídice da Mata (1993-1996) ou refrearam certas pretensões ordenadoras de planejamento e controle do uso do solo, convivendo sem traumas com o capital imobiliário, caso especialmente do primeiro, ou tiveram dificuldades e/ou confrontos diretos com certas coalizões privadas (Dantas Neto, 2000).

A influência privada sobre a gestão da cidade alcançou contornos mais radicalizados durante as gestões de Fernando José e Lídice da Mata. Na primeira, uma grave crise política e administrativa configurou uma "radical privatização do poder local", quando credores privados passaram a gerenciar o erário público, controlando inclusive a folha de pagamentos de pessoal (Dantas Neto, 2000, p.76). Na segunda, se configurou o que foi conhecido como o "sequestro da receita municipal" por parte de cinco empreiteiras credoras (Ivo, 2002). Assim, esse último governo acabou se convertendo em um marco da vulnerabilidade do poder local em Salvador, tanto no que tange aos interesses privados quanto em relação ao governo estadual, que, nas mãos de ACM, investiu deliberada e agressivamente contra a gestão municipal a partir de um cerco midiático de desqualificação da gestão, de uma guerra urbana sobre o espaço físico de mobilidade através da superposição de ações que criou desordem e mal-estar aos cidadãos e do bloqueio de recursos legais de impostos e execução financeira (Ivo, 2002).

Como se observa, a configuração do poder político local em Salvador desde a década de 70, e mesmo após a redemocratização e a constituição de 1988, sempre esteve às voltas com sua vulnerabilidade, tanto frente ao poder político estadual quanto frente à coalizão de interesses privados que operam sobre a cidade. A partir dos anos 90 uma nova estratégia começa a ser utilizada para superar determinadas limitações, o empresariamento urbano.

\section{Empresariamento urbano e laissez-faire territorial em Salvador na virada do século $X X$}

As estratégias de empresariamento urbano na cidade do Salvador tiveram início já na gestão de Lídice da Matta, governo considerado de esquerda e de oposição ao governo estadual, no início dos anos 90. Em Salvador, esse processo se expressou:

[...] na promoção de ações e eventos pontuais como: conferências e reuniões de cunho internacional; ênfase na profissionalização do carnaval e na atração do parque Atlântico, realizadas através do estímulo a parcerias público-privadas, com menor apoio do marketing (à exceção do carnaval), associada a uma racionalidade que buscava criar condições de desenvolvimento e crescimento econômico, como condição também necessária à superação da pobreza (Ivo, 2002, p.26).

Após esse governo, essas estratégias se aprofundaram com as duas gestões de Antônio Imbassahy (1997-2004), político ligado ao grupo carlista. Durante os dois mandatos o prefeito teve apoio dos governadores do mesmo grupo político, o que the garantiu condições distintas de governo. Segundo Ivo (2002), a governabilidade 
dessa gestão se fundamentou principalmente numa dependência administrativa da cidade ao governo do estado. A forte coalização entre as esferas de governo, articuladas em torno da liderança de ACM e do partido, chegou ao ponto de não haver uma clara separação dos limites das responsabilidades das ações entre as duas instâncias. Por conta disso, a dependência intergovernamental deixou de figurar como competição e se revestiu de positividade em termos de parceria solidária, união e ordem. A cidade se integrou ainda mais à dinâmica competitiva do mercado, com o reforço da sua imagem urbana, o estímulo à produção lúdico-cultural, incentivos fiscais e provisão de infraestrutura:

Nessa linha observa-se, em Salvador, uma concentração de ações em torno do turismo, valorizando a inovação cultural, elevando a qualidade do meio urbano (através da adoção de desenhos e propostas arquitetônicas arrojadas) nos atrativos de consumo e entretenimento (shoppings, marinas, festivais e espetáculos, urbanização litorânea, etc.) dinamizadas como estratégias de renovação urbana (Ivo, 2002, p.26).

Essa estratégia também se plasmou na construção de um mecanismo ideológico de coesão social, através de incentivos identitários e fortalecimento da imagem da cidade, criando um otimismo, especialmente nas áreas centrais voltadas para o eixo turístico (Ivo, 2002). Aprofundou-se, nesse novo contexto macroeconômico e político, a relação entre a coalizão de interesses privados e o poder local, fato ilustrado pela aprovação de um novo PDDU (Plano Diretor de Desenvolvimento Urbano) em 2004. Segundo Carvalho e Pereira (2013), esse plano foi gestado e orientado para os interesses do mercado imobiliário pois flexibilizou e alterou as normas urbanísticas de modo a facilitar a acumulação de mais-valia urbana. O plano alterou fundamentalmente os parâmetros construtivos, ampliando a elevação do gabarito das áreas valorizadas da cidade e foi questionado judicialmente porque, além de ignorar as disposições do Estatuto da Cidade, foi aprovado pelos vereadores na calada da noite, fato que impulsionou o Ministério Público a entrar com um processo. O processo não foi adiante porque quando a ação foi julgada o plano já tinha sido revisado, mantendo as mesmas características principais (Carvalho e Pereira, 2013).

Ao longo dos anos 90, além das ações da prefeitura municipal, destacaram-se também um conjunto de intervenções, especialmente voltadas para o turismo, do governo do estado sobre a cidade e sua região metropolitana. Nesse momento, o regionalismo político típico do carlismo (Pereira, 2017), com a valorização da cultura, das manifestações e dos atributos naturais da Bahia, se volta à lógica da atratividade turística e da busca de capitais numa clara competição com outros possíveis destinos, nacionais e internacionais.

Em 2004, foi eleito prefeito de Salvador João Henrique do Partido Democrático Trabalhista (PDT), apoiado por uma coligação formada por partidos de centroesquerda, criando expectativas aos setores progressistas. O slogan da gestão, "Prefeitura de Participação Popular", reiterava as promessas do bloco anti-carlista. Não obstante, como frisaram Carvalho e Pereira (2011), além da participação popular não ter se configurado, uma vez que a relação com os movimentos foram principalmente de cunho clientelista, ao longo desse período houve uma mudança de orientação da Prefeitura. Em 2008 a prefeitura adotou outra marca com o slogan 
"Prefeitura de um Novo Tempo", com um conjunto de edifícios ao fundo, demonstrando, segundo Carvalho e Pereira "a adesão e a busca de identificação da Prefeitura Municipal de Salvador com o discurso do empresariamento urbano" (2011, p.19).

Já em 2006 a Prefeitura demonstrou a sua vinculação com os interesses das coalizões privadas quando resolveu permitir a grandes empresas produtoras de cerveja e refrigerantes construir e gerenciar restaurantes na Orla de Salvador, realizando uma espécie de privatização de trechos das praias, iniciativa que acabou não se concretizando. Em 2008, foi feita uma revisão do PDDU de 2004 que previa um incremento nos parâmetros urbanísticos do aproveitamento do solo (Carvalho e Pereira, 2011).

A sua vinculação à lógica do empresariamento se aprofundou ainda mais na segunda gestão. Em 2010, a Prefeitura lançou um conjunto de projetos pouco integrados que foram doados por empresas do setor imobiliário à cidade. Sob o título de "Salvador Capital Mundial" propunha um amplo leque de intervenções para direcionar o desenvolvimento da cidade. Apesar da ênfase midiática em torno da "cidade pátria" (Vainer, 2000), o projeto teve repercussão bastante negativa por conta da oposição de alguns vereadores, da imprensa e de organizações da sociedade civil. Além desse "projeto", a flexibilização das normas de uso do solo e construção e a estreita articulação entre o governo local e o capital imobiliário ficaram patentes também com a ampliação do uso das Transcons, instrumento urbanístico que cria a "transferência do direito de construir" (Carvalho e Pereira, 2013).

Em 2011, por conta da necessidade de preparação para a Copa do Mundo de 2014, o prefeito justificou que "era preciso mudar as regras". Foi aprovada uma nova LOUOS (Lei de Ordenamento, Uso e Ocupação do Solo), alterando dispositivos do PDDU, reduzindo a representatividade dos Conselhos da Cidade e Meio Ambiente, ampliando o gabarito da Orla Atlântica, entre outras ações (Carvalho, 2013). Ao final do mandato, foi enviado ainda a câmara de vereadores um conjunto de projetos que legalizavam e institucionalizaram as transformações urbanísticas buscadas ao longo de todo o mandato, ainda que o PDDU e a LOUOS estivessem sob judice. Em uma avaliação sobre a referida gestão municipal, Carvalho e Pereira (2013) assim a caracterizaram:

Todos os seus grandes projetos têm em comum a falta de transparência, de discussão, de participação pública, com o repasse das atribuições tradicionais do Estado para uma coalizão de interesses privados (empreiteiras de obras públicas, empreendedores imobiliários, concessionários de serviços públicos, empresas de consultoria) que vem transformando a cidade em commodity e direcionando seu desenvolvimento em função dos interesses imediatos dos integrantes dessa coalizão (p.20).

As duas gestões de João Henrique tiveram relações complexas com o governo estadual, passando somente dois anos com o seu apoio. Entre idas e vindas, passou a maior parte do tempo sustentado por um correligionário que ocupava o cargo de ministro da integração nacional.

Esta gestão municipal foi bastante ilustrativa daquilo que Swanstrom (apud Logan e Molotch, 1987) chamou de estrategistas do crescimento que operam sobre a 
base do "capitalismo irrestrito", tendo como resultado aquilo que Torres (2009) denominou de um verdadeiro "laissez-faire" territorial.

\section{A gestão urbana na Salvador contemporânea: governo empresarial e com- petição intergovernamental}

A partir de 2013, chega à PMS o atual prefeito ACM Neto. No que tange à questão urbana, sua gestão pode ser analisada, de maneira geral, a partir de cinco grandes eixos: a) ajustes nas contas públicas, especialmente através do aumento de impostos ligados ao uso do solo; b) Elaboração de um grande planejamento estratégico para a cidade (Plano Salvador 500), revisão da legislação urbanística (PDDU e LOUOS) e modificações dos marcos regulatórios para a prestação de alguns serviços públicos através de PPPs (parcerias público-privadas); c) grandes projetos de requalificação urbana e a construção de grandes equipamentos; d) incentivo ao turismo e à indústria de entretenimento, e e) reordenamento e controle do espaço urbano.

Como ACM Neto se apresentou como candidato à PMS em 2012 enquanto oposição aos governos federal e estadual, ambos ocupados pelo PT, utilizou como um dos principais apelos de campanha a defesa da autonomia de Salvador através dos ajustes nas contas públicas. Há muito figurava na política local a ideia de que Salvador tinha uma baixa arrecadação e que só poderia ter uma boa gestão se vinculada politicamente às demais esferas federativas. Nesse sentido, já naquele momento ACM Neto defendia a necessidade de "arrumar a casa", colocando a questão fiscal como uma ação fundamental para sua futura gestão, que foi marcada administrativamente pelo mote da racionalização e do saneamento das contas públicas.

Entre as diversas ações levadas a cabo, a mais representativa foi a Reforma Tributária, que começou com o aumento do IPTU (Imposto Territorial Urbano), em alguns casos em até $35 \%$, através de uma atualização do cadastro imobiliário e da planta genérica de valores de Salvador. Com isso, o valor dos impostos passou a ser calculado pelo preço de mercado. Esse aumento, segundo os discursos oficiais, permitiu, por outro lado, a ampliação do número de imóveis isentos. A Reforma pautou ainda a ampliação do número de contribuintes do ISS (Imposto sobre Serviços).

A sua tramitação foi bastante tumultuada e teve grande resistência das incorporadoras imobiliárias, uma vez que inicialmente previa a cobrança de uma alíquota de 5\% ao setor. Segundo seus representantes, a cobrança do ISS sobre as incorporadoras iria agravar a crise do mercado imobiliário, além de ser inconstitucional, uma vez que o setor já pagaria 3\% de ITIV (Imposto sobre Transferência Inter Vivos). O prefeito se reuniu com os empresários, representados pelo SINDUSCON (Sindicato da Indústria da Construção do Estado da Bahia) e ADEMI (Associação dos Dirigentes de Empresas do Mercado Imobiliário da Bahia), na tentativa de resolver o imbróglio. Preferindo recuar ao risco da judicialização, o Executivo fez uma emenda à reforma original propondo a não cobrança do imposto. A nova emenda foi reprovada pelos vereadores e a cobrança foi mantida na lei aprovada pelo legislativo. Porém, o prefeito vetou a cobrança justificando razões jurídicas e econômicas, a última explicada devido ao número de empregos gerados pelo setor imobiliário. 
A prefeitura atualizou ainda o cálculo do ITIV passando a utilizar preços compatíveis com os praticados no mercado, muitas vezes superando esses valores. A mudança também gerou alta resistência do setor imobiliário e, sobretudo, dos compradores de imóveis. Devido às pressões, a prefeitura permitiu o parcelamento do imposto para os imóveis adquiridos na planta. Além disso, passou também a efetivar a cobrança da taxa de Foro com estimativa de arrecadar R \$ 28 milhões na época. Outra estratégia importante para aumentar arrecadação foi a desafetação de 62 imóveis públicos, muitos em bairros valorizados da cidade.

A importância das ações relativas a esse eixo se refere à maneira como o prefeito utilizou o solo urbano como "moeda" principal para galgar a autonomia fiscal (e de alguma forma política) do município. Por vezes, isso o levou a entrar em conflito com o mercado imobiliário, quando seus interesses políticos estavam em jogo, mas, de maneira geral, também fica clara a sua posição como um agente público que age em consonância com a lógica desse mercado, fato que ficará ainda mais evidente na análise dos demais eixos da sua gestão. Como apontam Dardot e Laval (2016), sob a égide do neoliberalismo o Estado deve ser entendido como uma entidade inteiramente integrada ao espaço de trocas, no sistema de interdependência dos agentes econômicos. Nessa medida é relevante considerar o lugar de destaque das incorporadoras enquanto agente econômico importante no desenvolvimento das políticas do urbano em Salvador.

Um segundo eixo da atual gestão urbana em Salvador diz respeito à elaboração de um plano estratégico de longo prazo para a cidade, que apareceu desde o início da gestão. O Plano Salvador 500 teve como horizonte o ano de 2049, quando a cidade completará 500 anos e tinha por objetivo "lançar as bases para o desenvolvimento sustentável da cidade para os próximos 35 anos, com ênfase no aumento dos índices de qualidade de vida da população e na elevação da autoestima dos cidadãos" (PMS, 2013, p.87). Lançado em 2014, teve com uma de suas primeiras metas atualizar o PDDU, que havia passado por contestações e processos de judicialização, e criar uma nova LOUOS, pois, segundo o prefeito:

A cidade está parada do ponto de vista da expansão imobiliária e da discussão de sua legislação ambiental. O que nós queremos é desatar todos esses nós sem os vícios do passado, fazendo uma audiência com ampla participação popular, garantindo que todos possam contribuir com esse debate (Ibahia) ${ }^{7}$.

ACM Neto havia tentado liberar partes do PDDU e da LOUOS de Salvador em 2013, com o objetivo de garantir a construção de empreendimentos que eram encarados como um legado da Copa do Mundo, hotéis, torres comerciais e shoppings. Mas, como visto, as legislações aprovadas na gestão anterior tramitavam na Justiça. O prefeito buscou construir um acordo com o Ministério Público para desjudicializar a questão, mas a LOUOS foi julgada inconstitucional. Passou-se a ser discutida então a modulação de algumas definições da lei. O presidente da ADEMI à época declarou que a insegurança jurídica sobre a questão prejudicou a construção civil e o mercado imobiliário, ocasionando uma redução dos lançamentos em Salvador. 
Com o lançamento do Plano Salvador 500 a prefeitura retomou a discussão sobre a LOUOS e o PDDU e em 2016 as duas leis foram sancionadas. Segundo Gomes (2019), o PDDU alterou o zoneamento da cidade com a ampliação do coeficiente de aproveitamento do solo autorizando construções de até 25 andares em quase toda a orla atlântica de Salvador, ou seja, permitindo que praticamente toda a área edificável da cidade fosse ocupada com alta densidade construtiva e demográfica dentro de um padrão vertical de grande porte. Além disso, visando atrair investimentos, o novo plano flexibilizou a legislação urbanística criando novas áreas para Operações Urbanas Consorciadas (OUC):

[...] um instrumento urbanístico que cria oportunidade para que o potencial construtivo seja utilizado em um espaço da cidade preestabelecido, visando transformação diferenciada estrutural a ser ofertada em leilões públicos, havendo um regime de exceção com a suspensão dos parâmetros urbanísticos. [...] Trata-se de uma transferência do patrimônio da cidade, que é o direito de construir, aos agentes imobiliários (Gomes, 2019, pp.181-182).

O PDDU elaborado por essa gestão foi considerado, como destacou Santos (2016), o mais participativo da história da cidade. No entanto, conforme salientou a autora, esse processo foi esvaziado de sentido político, uma vez que houve pouca representatividade de grupos organizados e movimentos sociais, assim como baixa participação de mulheres e jovens, sendo os principais interlocutores membros do Ministério Público e grupos técnicos de fiscalização. O processo foi esvaziado também de conteúdo, já que grandes projetos para a cidade já vinham sendo executados enquanto se desenrolava o processo participativo. Para Santos (2016), a participação social nesses planos se deu fundamentalmente para garantir segurança jurídica e legitimar politicamente o processo, evitando protestos e manifestações fora dos canais institucionais.

Assim, com a aprovação das referidas leis a prefeitura municipal exerceu um papel importante no desbloqueio da máquina de crescimento (Logan e Molotch, 1987) que estava relativamente paralisada por conta da insegurança jurídica gerada anteriormente, construindo as bases para um regime de desenvolvimento (Stone, 1993). Nesse sentido, é interessante retornar à crítica que Marques (2017) faz ao conceito de "máquinas de crescimento". Em sua interpretação, como o conceito advém do contexto estadunidense onde o federalismo fiscal estrangula as cidades criando uma realidade onde elas são fundamentalmente dependentes de investidores privados, o modelo não se encaixaria ao Brasil, onde os níveis locais de poder têm acesso a recursos financeiros significativos derivados de repasses automáticos e/ou condicionados por políticas. O desenho do federalismo brasileiro diferenciaria a política do urbano no Brasil, que não seria tão dependente de elites locais e interesses econômicos.

No caso de Salvador, a questão fiscal se mostrou extremamente importante para ACM Neto, especialmente para garantir a autonomia política do município frente aos governos de oposição estadual e federal. Ainda assim, a prefeitura municipal manteve-se muito próxima aos interesses privados. A questão fiscal permaneceu como parte relevante da justificativa para esta vinculação, na busca de parcerias, especialmente para a realização de festas e do carnaval, como se verá adiante, ou para o desbloqueio das atividades imobiliárias no município. Nesse sentido, pode- 
se considerar que a cidade permanece vinculada à lógica das máquinas de crescimento, se não por uma inexorabilidade fiscal, pelo menos por um interesse político, como reconheceu o próprio Marques (2013) em outra oportunidade.

Entre as mudanças legislativas se destaca também a criação de um novo marco regulatório para a prestação de alguns serviços públicos. Em 2016 foi promulgada a lei $\mathrm{N}^{\circ}$ 9091/2016 que alterou a antiga lei de PPPs da cidade (lei $\mathrm{N}^{\circ} 6975 / 2006$ ) e instituiu o "Programa de Parcerias Público-Privadas de Salvador". Atualmente encontra-se em consulta pública o projeto de PPP de iluminação pública da cidade. Desde o planejamento estratégico (2017-2020), a prefeitura tinha como meta instalar ou modernizar 35 mil luminárias com tecnologia LED ou superior, num valor estimado de R \$ 92 milhões, além de propor a ampliação da arrecadação da contribuição para o Custeio dos Serviços de Iluminação Pública (COSIP). É interessante notar que a nova lei define prioridades quanto à origem e tipo de capital que poderá se associar para a conformação da PPP através de um "incentivo à participação de arranjos produtivos locais ou regionais, de micro e pequenas empresas, quando couber, e à utilização de mão de obra local ou regional" (Salvador, 2016).

Um terceiro eixo da gestão da cidade nos últimos anos tem se vinculado a implantação de projetos de requalificação urbana e a construção de grandes equipamentos. Eles têm uma clara associação com as estratégicas de city marketing, que buscam reposicionar Salvador no quadro competitivo nacional, especialmente no turismo. A maior vitrine da primeira gestão foi o projeto de requalificação da orla marítima da cidade, pois como declarou o prefeito seria um "absurdo" o fato de Salvador ter sido ultrapassada por outras capitais do Nordeste na atração de turistas. Preocupado com essa indústria e com a perspectiva de "vender [a imagem] Salvador no Brasil e no exterior", afirmou em diferentes oportunidades:

Por que a orla de Salvador não pode ser tão boa ou melhor que as de outras capitais do Nordeste, como Maceió e Aracaju? Salvador tem potencial enorme para o turismo de sol e praia. Precisa só de um prefeito com capacidade de articulação com outros organismos da sociedade, competência, boa equipe e projetos para fazer (Site Oficial de ACM Neto, 23/09/2012).

Salvador tem uma orla feia, até mesmo cidades menos importantes que a nossa têm a orla melhor. O que vamos fazer é torná-la bonita, para atrair turistas e mais negócios para o baiano (A Tarde, 2012) ${ }^{9}$.

O projeto de Requalificação da Orla foi lançado já no primeiro ano de governo e dividiu a orla da cidade, da Baía de Todos os Santos à orla atlântica. A execução do projeto completo foi estimada inicialmente em cerca de R\$111,6 milhões, captados pela Prefeitura através do PRODETUR - Programas Regionais de Desenvolvimento do Turismo. O primeiro trecho a ser executado foi o da Barra, bairro valorizado da cidade, onde se encontram alguns dos principais pontos turísticos de Salvador. A execução desse trecho custou cerca de R $\$ 58$ milhões, quase a metade do valor estimado global, e foi operada pela construtora Odebrecht, contratada através de RDC (Regime Diferenciado de Contratações), modelo de contratação

Publicado no jornal A Tarde de 03/09/2012.

Disponível em https://atarde.uol.com.br/bahia/salvador/noticias/1567400-acm-neto-apresenta-projeto-da-orlade-itapua 
menos burocratizado, que foi promulgado no Brasil para agilizar as obras da Copa do Mundo de 2014.

Diversos trechos da Orla da cidade foram requalificados, contando com licitações e empresas diferentes para a realização dos projetos e da intervenção. Isso implicou em um desconhecimento público dos valores finais do projeto global, pois os processos licitatórios e os contratos firmados (e seus aditivos) não eram de fácil acesso. Os grupos empresariais envolviam desde grandes empresas nacionais da construção civil, como a já citada Odebrecht, quanto empresas regionais e locais, como a Campbel e Campbel, San Juan, BSM, NM, entre outras (Ferreira, 2019).

A PMS também requalificou e construiu alguns mercados municipais. O Mercado do Rio Vermelho se destaca pois passou por um processo de enobrecimento. Destaca-se o antigo Mercado do Peixe pelo processo de enobrecimento; espaço popular e vinculado à colônia de pescadores do bairro, deu lugar à Vila Caramuru, novo espaço "gourmet", patrocinado por uma marca de cerveja que obteve o monopólio dos seus produtos e composto por restaurantes e bares, cujos quiosques são administrados por três empresas que ganharam uma concessão de 15 anos.

$\mathrm{Na}$ segunda gestão dois grandes projetos se destacam, o Centro de Convenções de Salvador e o BRT (Bus Rapid Transit). Em 2020, a prefeitura inaugurou o Centro de Convenções de Salvador, com um investimento de R \$ 130 milhões, que será administrado por uma empresa francesa pelos próximos 25 anos. Desde 2015, a cidade não dispunha de um centro de convenções, pois o antigo espaço para realização de eventos foi fechado pelo governo do estado devido a problemas estruturais na construção. Durante este período o trade turístico pressionou bastante os poderes públicos, uma vez que considerava o segmento do turismo de negócios como um dos mais importantes da cidade. A sua construção estava prevista no plano estratégico da gestão 2017-2020. Segundo este plano, este equipamento era considerado um investimento importante da prefeitura municipal de Salvador pois tinha como objetivo resgatar a capacidade de atrair grandes eventos de negócios e culturais para a cidade (PMS, 2017). Após a construção do equipamento, demarcando claramente uma competição com o governo estadual, especialmente por conta do ano eleitoral, a prefeitura divulgou em suas peças publicitárias: "A Bahia precisava. A prefeitura fez".

Em 2018 a prefeitura municipal lançou o projeto de três linhas de um BRT, com um valor estimado em R $\$ 850$ milhões. A primeira linha foi licitada e teve como vencedor o consórcio conformado pelas empresas Camargo Correa infraestrutura SA, Construções e Comércios Camargo Correa SA e Geométrica Engenharia de Projetos LTDA, grandes grupos nacionais do capital da construção civil. Tal projeto foi bastante questionado por especialistas e por grupos da sociedade civil. Os primeiros criticaram a falta de uma visão integrada necessária para a mobilidade na metrópole, como a falta de articulação com outros modais existentes como o metrô, que é de responsabilidade do governo do estado (Delgado e Brito, 2019). Os demais, especialmente ambientalistas, questionaram a supressão de árvores, além do tamponamento dos rios e da construção de elevados, que causam impactos sobre a paisagem e beneficiam ainda mais o transporte individual.

A maior parte desses projetos está na esteira de um processo claro de empresariamento da gestão urbana da cidade. No que tange essas estratégias, tal como destacou Harvey (1996), parece que Salvador se insere naquelas voltadas a se conformar como espaço de consumo, especialmente de bens culturais e naturais, com o 
sol e o mar. Não logrando se qualificar como competidora forte para atração de atividades de produção, por conta da sua posição periférica no cenário nacional, entre outras questões como a qualificação da mão de obra, Salvador parece investir em fluxos voltados ao terciário, competindo com outras cidades brasileiras pelos turistas que chegam ao país, mas ao mesmo tempo se convertendo um dos polos do turismo doméstico. Segundo Ciccolella (2011), o setor que mais cresce nas cidades latino-americanas é o de serviços "banais", ligados ao consumo (shoppings, hipermercados, hotéis, restaurantes, casas de espetáculo, etc.), diferentemente daqueles que se concentram nas cidades globais.

Essa estratégia também está subjacente nas iniciativas da gestão urbana do atual prefeito da cidade de incentivo ao turismo e à indústria do entretenimento. Além da tradicional ênfase dada ao carnaval em Salvador, foram criados novos festivais e festas, como o festival da cidade (que ocorre em março, aniversário de Salvador) e o festival da primavera, além da nova festa de réveillon que se apresenta como a maior do país.

Todos esses eventos são realizados através da parceria com empresas privadas, especialmente cervejarias, que os patrocinam e recebem o direito ao monopólio da venda dos seus produtos e à publicidade master. Mesmo as festas que são realizadas em espaços públicos acabam sendo reguladas e privatizadas para impedir que os produtos de outras marcas sejam comercializados, a partir do cadastro e controle dos vendedores ambulantes e do monitoramento contínuo das festas, que tem suas entradas realizadas a partir de totens de controle. Essa estratégia vem sendo colocada em prática pela prefeitura municipal desde o carnaval de 2014 e teve a questão fiscal como a principal justificativa, como relatou o prefeito:

Esse ano, praticamente, o Carnaval está sendo bancado pelas cervejarias. O que significa dizer que nós vamos ter mais dinheiro para educação, saúde, transporte público. Até 2013, a Prefeitura tinha que colocar R \$ 20 milhões do cofre do município no Carnaval. A partir deste ano o Carnaval vai dar um lucro de $\mathrm{R} \$ 10 \mathrm{mi}-$ lhões, graças à parceria com as cervejarias (Portal R7) ${ }^{10}$.

Esse processo de valorização de atributos lúdico-culturais como características atrativas da cidade culmina com o reconhecimento de Salvador em 2015 como cidade da música da rede de cidades criativas da UNESCO. A candidatura foi justificada pela prefeitura pelo objetivo "de potencializar os principais ativos da cidade - a cultura e o turismo"11, o que demonstra a relevância das redes internacionais para algumas cidades (Herrschel e Newman, 2017). Em 2019, por sua vez, Salvador foi a única cidade brasileira recomendada pelo jornal The New York Times como destino turístico.

De fato, o turismo assume contornos econômicos importantes para a cidade. Somente no verão de 2019/2020 a prefeitura estimou a presença de 3,6 milhões de visitantes à cidade, entre turistas de outras cidades do estado, do país e estrangeiros. Durante o carnaval de 2020, uma pesquisa do Observatório de Turismo do estado da Bahia estimou a presença de 650 mil visitantes em Salvador, com taxa

10 Disponível em https://noticias.r7.com/bahia/prefeito-acm-neto-fala-sobre-monopolio-das-cervejarias-nocarnaval-de-salvador-28082015

11 Disponível em http://www.cidadedamusica.salvador.ba.gov.br/ 
média de ocupação dos hotéis em torno de $90 \%$ e um gasto médio por pessoa de R\$ 2 mil, totalizando uma de receita de 1,25 bilhão para a cidade.

Por fim, as ações da prefeitura no que tange à questão urbana se referem a um conjunto de ações que versam sobre o reordenamento e controle do espaço da cidade. O planejamento estratégico do município colocou a ordem pública como um dos seus itens principais. Foi criada então a SEMOP (Secretaria Municipal da Ordem Pública) que implementou diversificadas ações, como a realocação do comércio informal no centro da cidade com o licenciamento dos vendedores e a regulamentação do comércio nas praias com o fornecimento de kits oficiais, mais uma vez patrocinados por grandes cervejarias.

Muitas dessas ações foram eivadas de críticas da sociedade civil e dos grupos diretamente afetados. É importante considerar a relevância que a "ordem" adquire na atual gestão. Ele vem se impondo aos grupos populares, em geral trabalhadores informais, sendo construída para que a cidade possa trilhar os objetivos pretendidos pela administração municipal: "a elevação da cidade a um novo patamar de metrópole cosmopolita, capaz de atrair novos negócios e investimentos sustentáveis" (PMS, 2013, p.7). Como destacou Vainer (2000), a cidade-mercadoria busca consumidores solventes, transformando-se assim em mercadoria de luxo. A pobreza e os pobres são vistos como problemas ambientais ou de paisagem, que precisam ser domesticados, regulados, controlados.

Como uma dimensão transversal a todos os eixos acima analisados, é fundamental destacar como o prefeito ACM Neto buscou valorizar os atributos da cidade do Salvador, especialmente após as intervenções realizadas. Assim, Salvador passou a ser a única no Brasil dentro do rol de cidades criativas da UNESCO, passou a ter o maior réveillon do Brasil, foi indicada internacionalmente como destino turismo etc. Considerando que o prefeito foi reeleito em $2016 \mathrm{com}$ mais de $70 \%$ dos votos em todas as zonas eleitorais, é possível dizer que ele vem se configurando, assim como destacou Harvey (1996), como um "prefeito carismático, um administrador urbano sagaz" que tem direcionado o desenvolvimento de Salvador ainda mais para a lógica do empresariamento. Isso vem sendo feito, inclusive, com o resgate do orgulho e do sentimento cívico dos citadinos, favorecendo o surgimento de um certo "patriotismo de lugar" (Logan e Molotch, 1987) ${ }^{12}$.

Diferentemente do antigo prefeito, que parecia lidar com a máquina de crescimento a partir do modelo do livre mercado, de um verdadeiro laissez-faire, o atual prefeito se assemelha a um modelo de gestão que Logan e Molotch (1987, p.68), citando os trabalhos de Swanstrom (1985), classificaram como um "capitalismo pragmático de estado", na medida em que compreende a importância das ações de governo para maximizar a máquina de crescimento, criando condições políticas favoráveis, especialmente a partir da cooptação e pacificação social.

O governo do estado da Bahia também vem intervindo sobre o espaço urbano da cidade, fazendo dela um claro objeto de disputa política. Em algumas regiões de Salvador os outdoors da prefeitura e do governo do estado se sucedem em publicização aos diversos projetos realizados. Em mensagem nas redes sociais às vésperas do período eleitoral de 2018 o ex-governador do mesmo partido elogiou Rui Costa

12 A coligação de ACM Neto nas eleições de 2016 se chamou "Orgulho de Salvador", o que demonstra claramente a construção desses símbolos de pertencimento e sentimento cívico. 
(atual governador do estado) pela conclusão da obra de uma das principais passarelas da cidade afirmando que "prefeitar também é com ele"13.

Embora a intervenção do governo do estado no espaço urbano da cidade venha se dando de diversas formas, a partir de pequenas obras de contenção de encostas e construção de passarelas e também através do financiamento do carnaval, destacam-se grandes projetos urbanos, principalmente de mobilidade e logística. Além da Arena Fonte Nova ${ }^{14}$, concluída no governo anterior de Jacques Wagner ,se sobressaem a Expansão do Sistema Metroviário de Salvador e Lauro de Freitas, o VLT do Subúrbio, a implantação dos corredores transversais (Linhas Azul e Vermelha) e o Sistema Viário Oeste, que inclui a construção da ponte SalvadorItaparica (ilha cujos municípios compõem parte da Região Metropolitana de Salvador).

O metrô de Salvador, após anos com sua obra parada e/ou com atraso, passou à responsabilidade do governo do estado em 2013, quando foi lançado um edital de licitação que indicou a parceria público-privada com modelo de concessão patrocinada para a implantação, operação e manutenção do sistema. A concessão de 30 anos foi ganha pelo grupo CCR, um grande player latino-americano do setor de concessões de infraestrutura. $\mathrm{O}$ contrato teve um valor estimado de aproximadamente $\mathrm{R} \$ 5,8$ bilhões e o total de recursos públicos estimados em cerca de $\mathrm{R} \$ 2,3$ bilhões na forma de investimento, pagamento de contraprestações e através da oferta de cotas do Fundo Garantidor Baiano de Parcerias (FGBP), criado em 2004 quando o sistema de parcerias público-privada entrou no ordenamento jurídico do estado (Ferreira e Coité, 2019).

O VLT do Subúrbio, que substituirá um antigo sistema de trens, depois de vários imbróglios jurídicos que suspenderam a licitação por suspeita de irregularidades e risco de prejuízo ao patrimônio do estado e ao interesse público, teve sua licitação relançada em 2018 e contrato assinado em 2019 também em modelo de PPP em concessão patrocinada. O consórcio vencedor foi o Skyrail Bahia, composto pelas empresas Build Your Dreams - BYD Brasil e Metrogreen, a primeira de origem de chinesa, e que se apresenta como "gigante global pioneira em energia limpa [...] presente em cinco continentes, mais de 50 países e em cerca de 200 cidades" 15 . Segundo o contrato, o valor do investimento da fase um foi estimado em $\mathrm{R} \$ 1,5$ bilhão e o contrato firmado foi de aproximadamente $\mathrm{R} \$ 2,9$ bilhões referente ao valor nominal total estimado de pagamentos a serem realizados pela conce-

13 A competição com a qual se reveste atualmente a relação da prefeitura de Salvador com o governo do estado tem produzido superposição de algumas ações e uma falta de complementariedade entre outras, como no caso da negação da prefeitura em participar da Entidade Metropolitana (instância institucional criada para coordenar as ações entre os municípios da Região Metropolitana de Salvador). Tem gerado também um autorreferenciamento dos diversos planos construídos e projetos implantados, o que tem produzido uma incapacidade de produzir cooperação.

14 Arena construída para a realização da Copa do Mundo de 2014. Em seu lugar existia o Estádio da Fonte Nova que, mesmo contra diversas considerações técnicas dos especialistas, foi demolido para a construção do novo equipamento. Ele opera a partir de uma PPP de concessão administrativa levada a cabo por um Consórcio conformado pelas empresas OAS e Odebrecht, grandes players da construção civil nacional, com operação por toda a América Latina e África. Os recursos públicos investidos durante os 35 anos da concessão chegam ao montante de aproximadamente R\$1.609,8 milhões (Gordilho-Souza, 2016).

15 Disponível em http://www.byd.ind.br/noticias/byd-assina-contrato-para-construcao-do-vlt-do-suburbio-emsalvador-ba/ 
dente a título de contraprestação anual máxima e aporte de recursos durante o prazo da concessão.

Este projeto tem sido objeto de muitas críticas, tanto da sociedade civil quanto de especialistas. As questões são variadas, mas versam sobre aspectos como o custo da passagem após a implementação do Monotrilho ${ }^{16}$, a destruição do sistema de trens que, com pequenas reformas poderia alcançar a rede estadual e nacional, e mesmo o contrato da PPP, que cede à concessionária o monopólio da exploração comercial das estações, o que implicaria na perda de postos de trabalho informais da população já pauperizada, entre outros aspectos.

Além de projetos de matriz ferroviária, o governo do estado tem também investido na construção de novas vias urbanas, em geral justificadas pela necessidade de ligação entre os diversos modais de transporte da cidade. Destacam-se as chamadas Linhas Azul e Vermelha, consideradas corredores de média e alta capacidade, a primeira com $12,7 \mathrm{~km}$ e a segunda com $28 \mathrm{~km}$ de extensão. Esses corredores envolvem a construção de diversos viadutos e túneis e foram contratadas através do Regime Diferenciado de Contratação às seguintes empresas respectivamente: Consórcio Transoceânico Salvador (formado pelas empresas Axxo, Queiroz Galvão, TTC e Engenharia Constran), a um preço global de cerca de R \$ 647 milhões, e Grupo OAS - Construtora OAS, a um preço global de R 581 milhões, segundo informações do próprio governo do estado.

Por fim, destaca-se ainda o macro projeto do Sistema Viário Oeste que engloba a ponte Salvador-Itaparica e que busca, segundo o discurso oficial, criar um novo vetor de desenvolvimento no estado, ligando o Recôncavo Sul e o Baixo o Sul à capital. Entre 2017 e 2018 foi lançada uma Proposta de Manifestação de Interesse vencida por um consórcio composto majoritariamente por empresas chinesas, mas licitação só foi lançada no final de 2019 pois o governo do estado estava esperando os empresários sinalizarem as alterações que julgassem necessárias no projeto físico e na proposta econômico-financeira. Finalmente o leilão foi ganho, em dezembro de 2019, pelo consórcio "Ponte Salvador Itaparica" das empresas China Railway 20 Bureau Group Corporation - CR20; CCCC South America Regional Company S.Á.R.L - CCCC SOUTH AMERICA e China Communications Construction Company Limited - CCCCLTD. O investimento do consórcio previsto é de R \$ 6 bilhões, enquanto o Governo da Bahia dará aporte de R \$1,5 bilhão e a gestão e administração da ponte terá duração de 30 anos. Em fevereiro de 2020, o Consórcio não se apresentou para a assinatura do contrato, que, segundo a imprensa, se deveu à crise do Coronavírus que já impactava a economia chinesa ${ }^{17}$.

O capital chinês se tornou um dos parceiros preferenciais do estado da Bahia e de todo o Nordeste brasileiro. Além do VLT e da Ponte Salvador-Itaparica, ele está presente em diversos outros projetos já implantados, como usinas de energia eólica, e em estudo, como um parque industrial e investimentos em portos.

A busca de atração desses capitais é uma das estratégias mais evidentes do governo do estado, como ilustra a declaração do governador Rui Costa dada em

16 O atual sistema de trens tem uma tarifa de $\mathrm{R} \$ 0,50$ e a nova deve ser de $\mathrm{R} \$ 4,00$, o que, segundo pesquisas do Ministério Público do Estado da Bahia, deve inviabilizar o seu uso pela maior parte dos moradores da região, que é uma das mais pobres da cidade. Disponível em https://www.mpba.mp.br/noticia/50169

17 Disponível em https:/www.metrol.com.br/noticias/cidade/87209,chineses-nao-aparecem-para-assinarcontrato-da-ponte-salvador-itaparica 
21/05/2019, que deixa patente a lógica do governo empresarial que atua com a mesma lógica dos agentes privados (Dardot e Laval, 2016):

O Porto de Aratu será sim contemplado com esses investimentos [chineses]. Eu não sei dizer se eles vão querer fazer concessão, uma grande reforma, construir um outro. Isso são eles que vão fazer (Bahia Econômica) ${ }^{18}$.

Conforme se observa, o governo do estado intervém menos no espaço urbano de Salvador, como era de se esperar, mas o faz fundamentalmente a partir de projetos públicos de larga escala, articulando basicamente o grande capital de construção (Marques, 2013) conformado por empresas nacionais e internacionais, com capital globalizado. Essas e outras intervenções, conforme descrito por Coité (2019), têm sido capitalizadas politicamente através de um poderoso marketing político em publicidades denominadas "Obras tamanho G de Governo do Estado" e "Modelo Bahia de Gestão", que busca legitimar uma forma própria de governança, evidenciada como eficiente e produtiva, e com uma clara orientação empresarial. Isso se expressa na participação do governo estadual no Fórum Intergovernamental Rede PPP e na criação de uma superintendência especializada em parcerias públicoprivadas dentro do governo.

\section{À guisa de considerações finais}

Este trabalho buscou em termos teóricos compreender as transformações do Estado e da gestão urbana no capitalismo contemporâneo. Frente aos processos de "neoliberalização" (Brenner, 2018) e as estratégias cada vez mais comuns de "empresariamento da gestão urbana" (Harvey, 1996), o artigo tem como preocupação fazer uma "economia política do espaço" (Stone, 1993), levando em consideração tanto a relevância dos grupos privados e dos chamados capitais do urbano (Marques, 2016) quanto das instituições, dos legados históricos e dos diversos atores e dimensões que intervêm sobre a dinâmica do desenvolvimento urbano, especialmente o poder político e suas coalizões (Molotch, 1976). Empiricamente, o artigo se debruçou sobre a realidade de Salvador, uma cidade pobre e periférica no sistema econômico e urbano brasileiro.

Nesse aspecto, quatro são as principais conclusões, que ilustram os dilemas dessa cidade. Em primeiro lugar, o desenvolvimento urbano de Salvador esteve historicamente vinculado aos interesses do mercado imobiliário e da construção civil e de uma elite política regional, que bloquearam as tentativas de regulação pública do espaço da cidade. Isso criou um legado, uma dependência de trajetória no que tange aos padrões de gestão urbana e da construção das coalizões do poder local (Marques, 2017). É importante destacar, nesse aspecto, a relevância do poder político e dos seus atores. Embora a influência privada nos negócios públicos tenha sido desde sempre marca do desenvolvimento urbano da cidade, as instituições formais e o contencioso político compõem um quadro a partir do qual ela se expressa.

18 Disponível em https://bahiaeconomica.com.br/wp/2019/05/21/porto-de-aratu-vai-receber-investimentos-dachina-e-ponte-precisa-de-novos-estudos-economicos-diz-rui/ 
Um segundo ponto importante é que, mesmo com a característica dependência do governo do estado, no arranjo político atual a gestão urbana do município tem sido disputada. A disputa por quem gere melhor a cidade, embora seja protagonizada por grupos políticos de partidos antagônicos na Bahia, está ancorada em lógicas e características semelhantes, como chamaram atenção Arantes (2000) e Dardot e Laval (2016). Ambos vêm colocando em marcha "máquinas de crescimento" (Molotch, 1976), ainda que baseadas em coalizões distintas. Enquanto a prefeitura municipal tem se vinculado aos capitais dos serviços públicos e especialmente ao capital incorporador, muitos deles de abrangência mais local, o governo do estado tem se vinculado mais fortemente aos grandes capitais da construção civil, majoritariamente com operações internacionais.

Outro ponto importante é que a fragilidade fiscal do município de Salvador, como limite administrativo ou como discurso, tem contribuído para a implementação de um programa de empresariamento urbano desde os anos 90. Tal programa foi implantado por coalizões políticas distintas e permanecem centrais na atual gestão municipal. A elaboração de um planejamento estratégico, a defesa do estreitamento das relações com o setor privado, a ênfase na criação de uma imagem da cidade direcionada, de um lado, à criação de uma coesão identitária e, de outro, voltada para a sua venda, assim como a flexibilização das normas de uso e controle do solo demonstram como a atual gestão vem assumindo o papel de promotora da cidade na divisão espacial do consumo, em uma busca de garantir/conduzir as condições necessárias para a atração e geração de negócios imobiliários, turísticos, de matriz cultural, etc. (Harvey, 1996; Arantes, 2000; Vainer, 2000; Dardot e Laval, 2016).

Por fim, se o desenvolvimento urbano da cidade permanece historicamente atrelado aos interesses dos capitais do urbano, o dado novo é a forma como o Estado passa a regular essa relação e as coalizões de interesse local. Para se conformar como um ator competitivo no cenário global houve uma transformação da ação pública que introjetou lógicas empresariais e se colocou na condição de parceira dos capitais. Nesse mesmo caminho, se instrumentalizou através da criação de planos e novos arranjos jurídicos para a implementação dessas parcerias, como as legislações sobre parcerias público-privadas. Diferentemente do passado, também aprofundou a internacionalização do desenvolvimento urbano local, seja a partir dos grandes capitais incorporadores e da construção civil, dos projetos financiados por agências multilaterais ou dos fluxos de pessoas e capitais vinculados ao turismo.

Este trabalho, portanto, analisou a dinâmica de uma cidade específica dentro das lógicas mais amplas de empresariamento urbano, discutindo o peso das diferentes comfigurações do poder político local e sua vinculação com as coalizões privadas. Novos estudos precisam ser elaborados para a compreensão dessa dinâmica em outros contextos urbanos, permitindo comparar as realidades para identificar tendências mais gerais e características concretas derivadas de cada contexto empírico.

\section{Agradecimentos}

Essa pesquisa foi possível graças ao apoio da rede do INCT Observatório das Metrópoles, especialmente do núcleo Salvador, e das bolsas de iniciação científica do PIBIC - CNPQ, 
UFBA e Milton Santos. Agradecemos em especial às/aos bolsistas Alice Ferreira, Joseane Carvalho, Lucas Coité e Victória Martins.

\section{Referências}

Arantes, O. B. (2000). Uma estratégia fatal: a cultura nas novas gestões urbanas. In O. Arantes, C. Vainer e E. Maricato (Eds.), A cidade do pensamento único: desmanchando consensos (pp.11-74). Petrópolis, RJ: Vozes.

Brandão, M. (1981). O último dia da criação: mercado, propriedade e uso do solo. In L. do P. Valadares (Org). Habitação em questão (pp. 71-94). Rio de Janeiro: Zahar Editores.

Brenner, N. (2018). Espaços da urbanização: o urbano a partir da teoria crítica. Rio de Janeiro: Letra Capital/Observatório das Metrópoles.

Carvalho, I. (2013). Capital imobiliário e desenvolvimento urbano. Cadernos CRH, 26(69), 545-562.

Carvalho, I., e Pereira, G. (2011). Capital imobiliário e dinâmica metropolitana. Congresso da Associação Latino-americana de Sociologia, Recife.

Carvalho, I., e Pereira, G. (2013). A cidade como negócio. EURE, 39(118), 5-26.

Castells, M., e Borja, J. (1996). As cidades como atores políticos. Novos Estudos CEBRAP, (45), 152-166.

Ciccolella, P. (2011). Metrópolis latinoamericanas: más allá de la globalización. Quito: OLACCHI.

Coité, L. (2019). Gestão corporativa e competição intergovernamental: as intervenções urbanas do governo do estado da Bahia em Salvador. XXXII Congreso Internacional $A L A S$, Lima, Peru.

Dantas Neto, P. F. (2000). Caminhos e atalhos: autonomia política, governabilidade e governança em Salvador. In A. B. L. Ivo (Org.), O poder da cidade: limites da governança urbana (pp. 51-84). Salvador: EDUFBA.

Dantas Neto, P. F. (2006). Tradição, autocracia e carisma- a política de Antônio Carlos Magalhães na modernização da Bahia (1954-1974). Belo Horizonte: Editora UFMG.

Dardot, P., e Laval, C. (2016). A nova razão do mundo: ensaio sobre a sociedade neoliberal. São Paulo: Boitempo.

Delgado, J., e Brito, J. (2019). Padrões de acessibilidade, processos espaciais e Rede Integrada de transporte de alta capacidade na Região Metropolitana de Salvador, Brasil. In H. Gomes, O. Serra e D. Nunes (Eds.), Salvador e os descaminhos do Plano Diretor de Desenvolvimento: construindo novas possibilidades (pp. 199-230). Salvador: EDUFBA.

Duverger, M. (1981). Ciência Política-Teoria e Método (3a. ed.). Rio de Janeiro: Zahar.

Ferreira, A. (2019). As intervenções da prefeitura municipal de Salvador. XXXII Congreso Internacional ALAS, Lima, Peru.

Ferreira, A., e Coité, L. (2019). As estratégias de empresariamento urbano do governo do estado da Bahia: uma análise da PPP do sistema metroviário de Salvador e Lauro de Freitas. X Congresso Brasileiro de Direito Urbanístico, Palmas, Brasil.

Gomes, H. (2019). PDDU de Salvador e a apropriação empresarial da cidade. In H. Gomes, O. Serra e D. Nunes (Eds.), Salvador e os descaminhos do Plano Diretor de Desenvolvimento: construindo novas possibilidades (pp.155-198). Salvador: EDUFBA.

Gordilho-Souza, A. (2016). Metrópole e gestão urbana corporativa: o que muda na produção recente das cidades brasileiras? Impactos e tensões na Região Metropolitana de Sal- 
vador. In S. B. de Melo e Silva, I. M. M. de Carvalho e G. C. Pereira (Orgs.), Transformações metropolitanas no século XXI: Bahia, Brasil e América Latina (pp.233-280). Salvador: EDUFBA.

Hall, P. A., e Taylor, R. C. R. (2003). As três vertentes do neo-institucionalismo. Lua Nova, (58), 193-224. Recuperado de https://www.scielo.br/pdf/ln/n58/a10n58.pdf

Harvey, D. (1996). Do gerenciamento ao empresariamento: a transformação da administração urbana no capitalismo tardio. Espaço \& Debates, Revista de Estudos Regionais e Urbanos, (39), 48-64.

Herrschel, T., e Newman, P. (2017). Cities Joining States as International Actors. In T. Herrschel e P. Newman, Cities as International Actors: Urban and Regional Governance Beyond the Nation State (pp.1-22). London: Palgrave Macmillan.

Ivo, A. B. L. (2002). Recomposição política, comunidade cívica e governança urbana. Cadernos Metrópole, (8), 9-32.

Jajamovich, G. (2013). Miradas sobre intercambios internacionales y circulación internacional de ideas y modelos urbanos. Andamios, 10(22), 91-111. Recuperado de http://www.scielo.org.mx/scielo.php?script=sci_arttext\&pid=S187000632013000200006\&lng=es\&tlng=es

Lessa, C., e Dain, S. (1983). Capitalismo associado: algumas referências para o tema Estado e Desenvolvimento. In L. G. de M. Belluzo e R. Coutinho (Orgs.), Desenvolvimento capitalista no Brasil: ensaios sobre a crise. Vol.I (pp.247-265). São Paulo: Brasiliense.

Logan, J., e Molotch, H. (1987). Urban Fortunes: the political economy of place. Berkeley e Los Angeles: University of California Press.

Marques, E. (2013). Governament, Political Actors and Governance in urban policies in Brazil and São Paulo: Concepts for a Future Rescarch Agenda. Brazilian Political Science Review, 7(3), 8-35.

Marques, E. (2016). De volta aos capitais para entender as políticas urbanas. Novos Estudos CEBRAP, 35(2), 15-33.

Marques, E. (2017). Em busca de um objeto esquecido: A política e as políticas do urbano no Brasil. RBCS, 32(95), 1-18.

Molotch, H. (1976). The City as a Growth Machine: Toward a Political Economy of Place. American Journal of Sociology, 82(2), 309-332.

Pereira, C. G. (2017). O jogo entre elites e instituições: as estratégias políticas de ACM Neto e a tradição carlista. Caderno CRH, 30(80), 237-255.

PMS (Prefeitura Municipal de Salvador). (2013). Salvador Construindo um novo futuro, 2013-2016. Salvador.

PMS (Prefeitura Municipal de Salvador). (2017). Planejamento estratégico (2017-2020): uma nova cidade para um novo tempo. Salvador.

Rivera, E. (2004). Teorías de la regulación en la perspectiva de las políticas públicas. Gestión y Política Pública, XIII(2), 309-372. Recuperado de http://www.gestionypoliticapublica.cide.edu/num_anteriores/Vol.XIII_No.II_2dosem/R ivera.pdf

Salvador. (2016). Lei $N^{o}$ 9092/2016: Institui o programa de parcerias público-privadas do município de Salvador (PPP Salvador) e dá outras providências. Salvador.

Santos, R. C. (2016). Quem participa? Participação Popular e Direito à Cidade: Um Estudo de caso do Plano Salvador 500. Dissertação de Mestrado em Direito, Universidade de Brasília. 
Stone, C. N. (1993). Urban Regimes and The Capacity to Govern: a political economy approach. Journal Of Urban Affairs, 15(1), 1-28.

Torres, H. (2009). Procesos recientes de fragmentación socio-espacial en Buenos Aires: la suburbanización de las élites. In P. Pírez (Ed.), Buenos Aires: La formación del presente (pp.241-265). Quito: OLACCHI.

Vainer, C. B. (2000). Pátria, empresa e mercadoria. Notas sobre a estratégia discursiva do Planejamento Urbano Estratégico. In O. Arantes, C. Vainer e E. Maricato (Eds.), A cidade do pensamento único: desmanchando consensos (pp.75-104). Petrópolis, RJ: Vozes.

Vasconcelos, P. de A. (2002). Salvador: transformações e permanências (1549-1999). Ilhéus: Editus. 